\title{
Profiting with Values: A Qualitative Approach to SMEs in the Informal Economy of Uganda's Central Region
}

\author{
Ismail Kintu $^{1}$, Yusuf Kiwala ${ }^{1} \&$ Faizo Buyinza ${ }^{1}$ \\ ${ }^{1}$ College of Business and Management Sciences, Makerere University, Kampala, Uganda \\ Correspondence: Ismail Kintu, Department of Accounting and Finance, College of Business and Management \\ Sciences, Makerere University, Kampala, Uganda. Pool Road, P.O.Box, 7062, Kampala. Uganda. E-mail: \\ kintuisma@gmail.com
}

Received: September 3, 2020

Accepted: October 20, $2020 \quad$ Online Published: November 26, 2020

doi:10.5539/ijbm.v15n12p169

URL: https://doi.org/10.5539/ijbm.v15n12p169

\begin{abstract}
The study sought to establish the core values which influence SME profitability in Uganda's informal economy. By employing a qualitative approach, interviews from twenty-five respondents were conducted. Data were analyzed by coding and networks with the help of the Atlas.ti 8 tool. The study findings indicate that: whereas the accounting profession defines profitability to be return on assets (ROA), return on investment (ROI), and return on equity (ROE), entrepreneurs in Uganda's informal economy do not understand these traditional profit measurement criteria. Instead, they understand sales and expenses. Besides, fairness, respect, responsibility, and cleanliness were established as core values that catalyze SME sales. It is important for the government through the private-sector foundation and traders' association to continuously train these entrepreneurs about financial matters. Also, the accounting professionals through the regulatory body may establish a wing that can help these informal traders in financial matters, the way the Uganda law society is approaching to help out vulnerable people who cannot afford the services of expensive lawyers.
\end{abstract}

Keywords: profitability, core values, informal economy, SMEs and qualitative

\section{Introduction}

The informal economy is branded by neither employment contracts nor social security (Henley, Arabsheibani \& Carneiro, 2009). Besides, Uganda is characterized by informal sector employment which provides low skills with poor pay and no access to social protection (International Labour Organisation decent work country programme, 2013-2017). Perhaps this is because entrepreneurs in the informal economy prefer to minimize costs and ensure profitability which is the goal of most firms. It is important to understand that most Small and Medium Enterprises (SMEs) in Uganda are informal (Ministry of Finance, Planning Economic Development, 2008: Uganda Investments Authority and Ernst \& Young, 2011), but their contribution to Uganda's Gross Domestic Product (GDP) is about 75\% (Uganda Investment Authority, 2012). Moreover, about 95\% of the labour force in Uganda are employed in the informal economy (International Labour Organisation decent work country programme, 2013-2017). This underscores the need to have empirical research about the operations of SMEs in Uganda's informal economy.

Although SMEs in Uganda's informal economy contribute enormously to Uganda's labour market and GDP at large, there is a relative research paucity about their operations. Whereas there is a myriad of research findings in developed/developing economies about ethical behaviour and firm performance (Roberts-Lombard et al. 2016: Wei \& Yazdanifad, 2014: Long, 2016 and Vercio \& Champion, 2006), there is, nevertheless, a paucity of studies focusing on ethics and profitability of SMEs in Uganda's informal economy. Having established the commonly practiced core values in Uganda's informal economy (Kintu, 2017), it is important to establish the relative purpose of such core values to firm operations (considering profitability lens), in Uganda's informal economy which is currently missing.

Core values have moved discourse from guiding principles of employee behaviour to influencing firm profitability. Moreover, Jelovac et al. (2011) assert that profitability is a core value. However, Jelovac et al. (2011)'s position does not prevail in Uganda. There is disregard of profitability as one of the commonly practiced core values in Uganda's informal economy. This resonates from (Kintu, 2017)'s findings of core values practiced in Uganda's informal economy. Although there are innumerable studies that indicate that core values 
significantly influence firm profitability, for instance, Boulter (2008) and Loch et al. (2012), contextualizing SMEs in Uganda's informal economy is so far missing hence justifying this study. Furthermore, local studies such as; Abaho et al. (2016) focused on firm capabilities and entrepreneurial performance, Kakeeto-Aalen et al. (2014) focused on trust and customer satisfaction. Core values impart employee commitment (Ketprapakorn \& Kantabutra, 2019). Therefore, this study seeks to provide a body of literature that is currently missing.

In addition to the above background, the study aimed to answer the following question; i) Do core values influence SME profitability in Uganda's informal economy? ii) Which core values influence SME profitability in Uganda's informal economy? The paper is organised into the following sections. Section one discusses the introduction and research questions. Section two discusses the theoretical framework and literature review, section three discusses methods employed in the study and section four discusses the study findings and conclusions.

\section{Literature Review}

\subsection{Theoretical Background}

In trying to guide the ethical behaviour of employees, Schmiedel et al. (2013) argue that core values need to be blended in all business processes. In this case, core values are principles that govern employees' behaviour (Lencioni, 2002). Furthermore, core values are significant in shaping morality in the workplace and promoting good work practices (Wright, Zammuto \& Liesch, 2017). This is indicative of the deontology theory which emphasizes principles and rules which oversee employee behaviour (Schwartz, 2005). Also, deontology provides that moral values or responsibilities are critical for the firm's goodness (Viviers, Bosch, Smit \& Buijs, 2008). Moreover, Abyad (2014) and Rakesh, Anusha, and Suresh (2016) contend that moral values guide on right or wrong within a firm. Besides, it can be argued that since moral values under deontology theory guide employees for the good of the firm as earlier discussed, such values can support firm efficiency and performance (Ferguson \& Milliman, 2008). For this study, performance is measured by profitability. This study is built on-premise that core values promote firm profitability (Boulter, 2008), thus the following construct.

\subsection{Core Values and Profitability}

For the firm to ensure high profitability, the demand for her products must match the ideal products and services it produces (Nishimura, 2011). It is further argued that for firms to earn profits, incomes generated must supersede expenses in a given time frame (Gang, 2016). To contextualize this study, however, arguments are raised that core values influence firm profitability. Whereas Boulter (2008) argued that core values that are well structured in a firm improve firm profitability, Jelovac et al. (2011) concluded that profitability is a core value. At the same time, Loch et al. (2012) argued that, although a firm needs to collect from trade receivables, fairness to clients can help to maximize firm profits. Furthermore, firms that trust and boost employee self-assurance are rewarded with high levels of profitability (Wei \& Yazdanifad, 2014). It is therefore indicated that core values help to improve a firm's financial performance specifically profitability. Also, Ard (2015) argues that core values keep employees involved in all firm processes hence more revenues and profitability. Besides, Ketprapakorn \& Kantabutra (2019) argue that core values enhance corporate sustainability through market leadership and high financial performance. At the same time, untrusted supervisors cannot achieve employee commitment at work, hence limited sales and low firm financial performance.

It is noticed, however, that the above discussion indicates that the contribution of core values to firm profitability is not yet contextualized in Uganda's informal economy SMEs as the literature reviewed is from developed economies, hence a need for this study. It is further argued that profitability is measured by gross profit (Madishetti \& Kibona, 2013). Besides, profitability can be measured by return on assets or return on equity (Park \& Jang, 2012; Logan, 2016). Since these profitability measures have not yet been tested in Uganda's informal economy for lack of proper accounting records, it is relevant to carry out the study investigating how profitability can be measured.

On the other hand, it can also be argued that it is challenging to measure profitability using the above measures in Uganda's informal economy since most SMEs do not keep proper records. The measures are appropriate to SMEs which can fully monitor their assets and equity. Since assets and equity need a high level of organisation and constant update, measuring firm profitability in the informal economy may be difficult.

Having discussed the relationship between core values and profitability of firms as indicated above, it is important to determine those specific values which can influence profitability. Scholars such as; Jurkiewicz \& Giacalone (2004), Michie \& Gooty (2005), and Schwartz (2005) developed core values showing how they influence employees' behaviour. At the same time, scholars such as; Buckley, Beu, Frink, Howard, Berkson, 
Mobbs \& Ferris, (2001), Chekwa, Ouhirra, Thomas \& Chukwuanu (2014) stressed the role of core values as a leadership aspect of organisations rather than a tool for financial performance. Since empirical research findings have indicated that core values enhance organisational leadership, in the same way, it can be argued that core values can enhance profitability in SMEs. However, this has not yet been studied in Uganda's informal economy hence a need for the study.

\section{Research Methodology}

\subsection{Research Design and Approach}

Following the research questions, the study adopted a qualitative approach. The qualitative approach aimed at establishing whether core values influence SME profitability, but first, by establishing the core values which influence SME profitability in the informal economy of Uganda's central region and how profitability is perceived by traders in Uganda's informal economy.

Under the qualitative approach, the researchers sought interviewees' opinions on the particular core values which influence SME profitability in the informal economy of Uganda's central region.

\subsection{Sampling Approach, Size and Study Scope}

Purposive sampling was adopted as a qualitative approach to select interviewees who participated in the study. This helped to gather interviewees' views about core values that influence profitability and whether core values influence SME profitability in Uganda's informal economy. The sample size was twenty-five respondents. This is considered to be adequate for a qualitative study (Creswell, 2013). Also, data were collected from Masaka, Mityana, Kampala, Mukono, and Wakiso towns because they are the most urbanized centers in the central region (Uganda Bureau of Statistics, 2010). For this study, the researcher interviewed one entrepreneur per SME per sector from each town. This is an equivalent of five participants from each town. The category of businesses considered for the study were: beauty salons, restaurants, mini markets, juice processing, and cosmetic processing. Also, participants were entrepreneurs who had the business experience of three or more years and adults of eighteen years and above. Entrepreneurs were selected for the interviews because they stay longer within business operations. Moreover, it was a cross-sectional study.

\subsection{Interview Approach}

Furthermore, an interview guide was designed to collect respondents' opinions about the core values which can influence profitability in Uganda's informal economy. The interview guide consisted of an introduction to give an overview of the content of the interview. The second part provided the respondent's biographical data and the last part contained questions about the practiced core value that influence firm profitability and whether core values influence firm profitability.

To gather respondents' opinions, face to face interviews were conducted using open-ended questions. The research team, however, had to first seek for respondents' consent. Overall the duration for each interview was thirty minutes.

The researcher sought the respondents' permission to be part of the study. Respondents were prepared on the subject matter of the study. As the lead researcher was interrogating the respondents, the research assistant was recording/taking notes. This is because the interviewees declined to be recorded using a voice recorder. After every interview, the lead researcher would look through the major points recorded by the research assistants and cross-check with the respondent immediately to confirm the major issues discussed in the interview.

The reliability for interviews was ensured by keeping an adequate sample size (Morse et al. 2002) and cross-checking data for possible mistakes. Furthermore, transparency and credible data were collected. Debriefing was also conducted to ensure the validity of the data.

\subsection{Analysis}

To generate proper meaning from the row interview data, the analysis was done through coding and categorizing data. But before the coding, re-transcribing, and proofreading field notes was done. The open and axial coding was done to develop categories and themes from the data. An analysis tool of Atlas.ti 8 was employed to help in data analysis.

To ensure conformity with ethics standards, permission to conduct this research was sought from the ethics committee of the University of Witwatersrand. In this regard, to ensure that participants were comfortable with the study, and ethics clearance was obtained from the University of the Witwatersrand central ethics committee. 


\section{Research Results and Discussion}

The qualitative interview response rate was $100 \%$ where all targeted 25 respondents gave their opinions. The number of respondents was 10 and 15, female and male respectively. The response rate enabled the establishment of extensive views about the core values and profitability of SMEs in the informal economy of Uganda's central region. Furthermore, data credibility was ensured by debriefing before and after the interviews and the sample size was adequate.

After a careful process of data editing and cleaning, coding, and categorization was done. Themes were developed. The following discussion provides more light on core values and profitability aspects in Uganda's informal economy.

To answer the research questions, interviewees provided opinions about core values that influence SME profitability. The study's research questions sought to establish the specific core values which influence profitability in SMEs of Uganda's informal economy and how they do. The following extracts provide interviewees with opinions about core values and profitability. First and foremost, it was difficult for all interviewees to explain profitability in their businesses. They were relating core values to sales with a few who would hint on how core values can help to reduce expenses. The figures 1 and 2 below can summarize the findings.

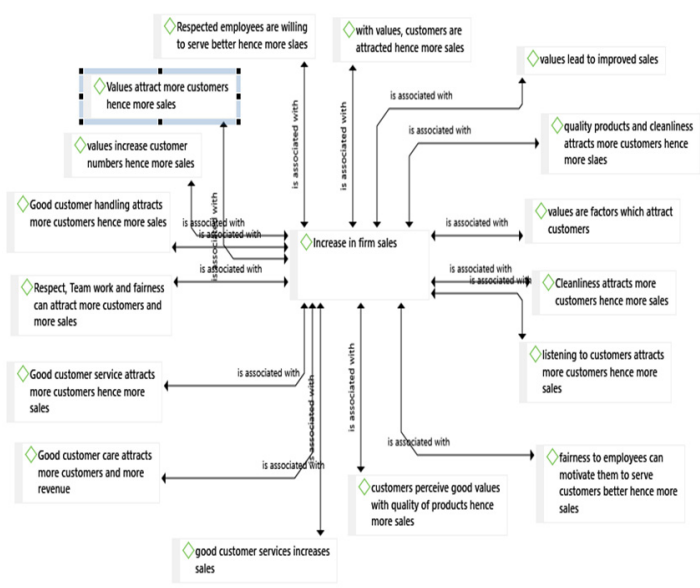

Figure 1. Values increase firm sales

Source: Primary data.

Figure 1 above indicates that values increase firm sales. Specifically, it is noted that respect, responsibility, cleanliness, and fairness are the values which mostly influence firm sales. It is also indicated that values create customer attraction to the firm hence more sales.

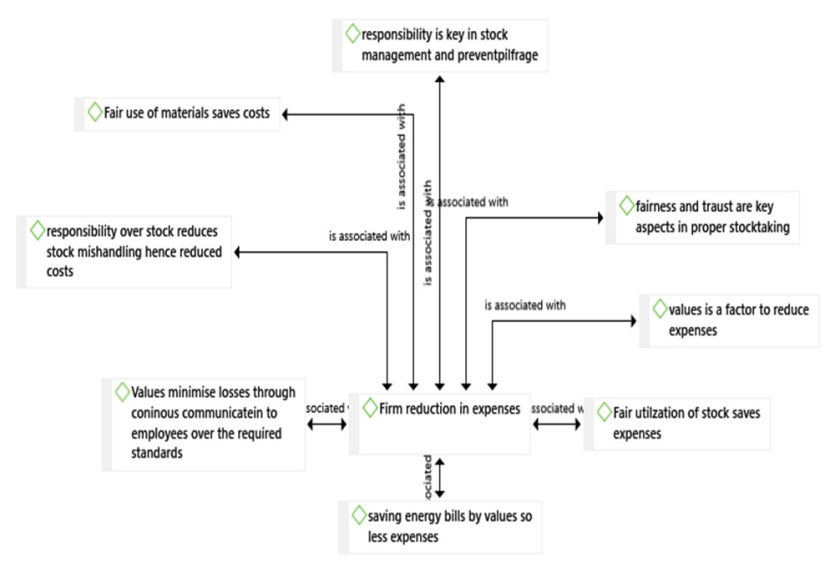

Figure 2. Values reduce firm expenses

Source: Primary data 
Figure 2 above indicates that values are essential in reducing firm expenses. Commonly it's about fair utilization of stock and being more responsible in managing stock that creates a difference in firm expenditure.

In the same vein, interviewees had much to say about the subject matter. For instance, interviewee No 25 from Mityana town, dealing in juice processing said that, '... Fair utilization of stock helps to reduce business expenses...' Furthermore, interviewee No 24 from Kampala operating a supermarket also observed that '...Values will be a factor to reduce expenses for instance workers will find it easy to switch off lights which are not in use. At the same time, sales will shoot up because of good customer care.....' Moreover, interviewee No 22 from Mukono operating a supermarket had to say, '.......Assigning each employee responsible for a section of stock will prevent shop-lifting hence minimizing losses. At the same time values will attract customers hence more sales....' Interviewee No 22 concurs with interviewee No 10 from Mityana who operates a restaurant. Most importantly, interviewees linked core values to sales. For instance; interviewee No 15, 20, and 21 said, '.... With values, customers have easily attracted hence more sales....' But interviewee No 19 from Wakiso dealing in cosmetics linked respect to sales and costs of a firm. He had to say, 'If employees are respected, they will be willing to share good information on how to reduce costs and how to improve sales....' Also, interviewee No 3 and 18 from Masaka and Wakiso respectively, and both operating salon businesses observed that cleanliness influences firm sales. They said, ' cleanliness will attract more customers hence more sales'. At the same time, interviewee No 13 from Wakiso dealing in cosmetics asserted that 'A business with good values will be perceived by customers as one which produces quality products, so there are increased sales.....' Furthermore, interviewee No 1 from Kampala dealing in cosmetics said, 'if employees provide service promptly and respect, energy bills will be saved so fewer expenses. At the same time, values lead to customer satisfaction which increases sales'. Also, interviewee No 4 and 6 from Mityana and Mukono respectively, both operating salon businesses said, 'Using the right material mix in the salon will save material cost and fairly using water will reduce the water bills. Good customer care will increase business sales'. From the above findings, we realize that; Core values influence sales and expenses in Uganda's informal economy rather than profitability as defined by accounting definitions, thus answering the research question of: 'Do core values influence SME profitability in Uganda's informal economy?'

In addition to interviewees' failure to link core values direct to profit measurements, the core values which would be easily linked to sales with a mild explanation of expenses were; 1) fairness and it had three-point of response references. 2) Respect, which had two points of response reference. 3) Responsibility which had three points of response reference and 4) cleanliness which had two points of response reference. Therefore; fairness, respect, responsibility, and cleanliness are core values in Uganda's informal economy which can influence sales but mildly explain expenses. Having provided the above discussion, it can be ascertained that the research question of: 'Which core values influence SME profitability in Uganda's informal economy?'

The above findings also lead to the formulation of the following propositions;

1. Core values, if well implemented and practiced, can influence SME sales and expenses in Uganda's informal economy.

2. Fairness, respect, responsibility, and cleanliness, if well integrated into the business processes, can attract customers as well as reducing business expenses in SMEs in Uganda's informal economy.

\section{Discussion}

Core values are helpful to organizations seeking to improve their performance (Hoffman \& Shipper, 2018). Turyakira (2018) contends that for businesses to be profitable, they must be ethical. Furthermore, Volker, Phil, Yehuda, and Aikaterini (2018) assert that fairness improves employee attitudes, influences buyer re-purchase, hence firm profitability. However, in Uganda's informal economy, since the entrepreneurs cannot define profitability in the way explained by formal accounting definitions, core values can easily be linked to sales performance. The results concur with Ard (2015) who argues that well-structured core values can improve organisations' revenues. Also, no interviewee explained how core values could directly influence profitability through traditional profitability-measurements. This is not to disagree with the literature reviewed in section two above, where scholars such as; Park \& Jang, (2012); Logan, (2016) contend that profitability can only be measured by traditional methods of return on assets or return on equity. But to reveal how entrepreneurs in Uganda's informal economy setting perceive profitability to be. Therefore, in Uganda's informal economy, entrepreneurs understand only sales and expenses as measures of profitability rather than return on equity or return on assets.

Whereas Gang, (2016) asserts that for firms to enjoy profits, incomes must exceed expenses, entrepreneurs in Uganda would not adequately demonstrate to this effect. Instead, they would explain how core values can either 
increase sales or reduce expenses.

Wei and Yazdanifad, (2014) provide for trust as a catalyst for firm profitability, however, the study established that trust is not any meaningful in Uganda's informal economy. This is in addition to establishing that entrepreneurs understand sales rather than profitability.

It is understandable, because, with the mediocrity level of formal education obtained by most of the entrepreneurs and lack of bookkeeping in the informal businesses, ascertaining the value of assets to generate the assets turnover or having a return on capital cannot be an easy task. Moreover, informal entrepreneurs do not have enough resources to hire accountants for bookkeeping. This is, therefore, to deviate from most of the literature which established that core values lead to firm profitability performance (For example, Boulter 2008, Lorch et al., 2012; Wei \& Yazidanifad 2014).

\section{Conclusion}

The study set to establish the core values which influence firm profitability and whether core values influence firm profitability. Whereas scholars in other spheres of the World concluded that core values influence firm profitability, a different direction was established in Uganda's informal economy. It is worth understanding that using a qualitative approach, all respondents were referring to sales but not profit. Therefore, informal traders in Uganda's central region derive satisfaction when they sell more than understanding the value of their assets and the return on investment. The study established that; fairness, respect, responsibility, and cleanliness are the core values that catalyze revenue generation in SMEs of Uganda's informal economy.

The situation explained above places the government and the accounting profession into a stroppy position of deciding whether to help these entrepreneurs in bookkeeping. The government on one hand realized that informality impedes revenue collections, and if entrepreneurs can define their assets and determine their returns well, the government may increase the tax base. On the other hand, accountants face a tradeoff, providing a pro-bono service to the informal entrepreneurs may waste their valuable time which would be spent elsewhere earning, but, they may need to improve the profession's image before the public. The accounting profession may learn from the legal profession which established a wing that provides affordable legal services to vulnerable people who cannot afford expensive lawyers. Such policy and management decisions may be difficult for both government and the accounting regulatory body.

Through the qualitative study, it was also established that the deontology theory is applicable to Uganda's informal economy. Behaving well and approaching business with morals can only improve business sales rather than causing business doom. This is through increased customer satisfaction and, therefore, increased sales revenue.

\section{Acknowledgments}

This is to acknowledge colleagues who have helped in assembling this manuscript. Also acknowledge the support provided by the college leadership.

\section{References}

Abyad, A. (2014). Morality, ethics and business. Middle East Journal of Business, 9(1), 41-45. http://doi.org/10.5742/MEJB.2014.91374

Ard, G. (2015). Culture-can happiness lead to money? Reeves Journal, 95(5), 14-15.

Boulter, J. (2008). Built to prosper: Commit to profitability. Chartered Institute of Management Accountants, $82(3), 18-20$.

Buckley, M. R., Beu, D. S., Frink, D. D., Howard, J. L., Berkson, H., Mobbs, T. A., \& Ferris, G. R. (2001). Ethical issues in human resource systems. Human Resource Management Review, 11(1-2), 11-29. http://doi.org/10.1016/S1053-4822(00)00038-3

Chekwa, C., Ouhirra, L., Thomas, E., \& Chukwuanu, M. (2014). An examination of the effects of leadership on business ethics: Empirical study. International Journal of Business and Public Administration, 11(2), 48-65.

Creswell, J. W. (2013). Qualitative inquiry and research design choosing among five approaches (3rd ed.). New Dehli: Sage.

Ferguson, J., \& Milliman, J. (2008). Creating effective organizational values: a spiritual leadership approach. International Journal of Public Administration, 31(4), 439-459. http://doi.org/10.1080/0190069070159083

Gang, S. S. (2016). Profitability analysis of Indian cement industry: A study during 2010-2015. International Journal of Research in Commerce and Management, 7(9), 83-86. 
Guha, A. B. (2010). Motivators and hygiene factors of generation X and generation Y: The test of two-factor theory. The XIMB Journal of Management, 7(2), 122-132.

Henley, A., Arabsheibani, G. R., \& Carneiro, F. G. (2009). On Defining and Measuring the Informal Sector: Evidence from Brazil. World Development, 37(5), 992-1003. http://doi.org/10.1016/j.worlddev.2008.09.011

Hoffman, C. R., \& Shipper, F. M. (2018). Shared core values of high performing employee-owned enterprises. Journal of Management, Spirituality and Religion, 15(4), 285-304. http://doi.org/10.1080/14766086.2018.1482474

Hussey, M. D., \& Eagan, P. D. (2006). Using Structural Equation Modeling to Test Environmental Performance in Small and Medium Size Manufacturers: Can SEM Help SMEs? Journal of Cleaner Production, 15, 303-312. https://doi.org/10.1016/j.jclepro.2005.12.002

International Labour Organisation. (2012). Decent work country program 2013-2017.

Jelovac, D., Van, D. W., \& Jelovac, A. (2011). Business and government ethics in the new and old EU: An empirical account of public-private value congruence in Slovenia and the Netherlands. Journal of Business Ethics, 103(1), 127-141. http://doi.org/10.1007/s10551-011-0846-5

Jurkiewicz, C. L., \& Giacalone, R. A. (2004). A values framework for measuring the impact of workplace spirituality on organisational performance. Journal of Business Ethics, 49(2), 129-142.

Kakeeto-Aelen, T. N., Dalen, J. C., Herik, J. D., \& Walle, B. (2014). Building customer loyalty among SMEs in Uganda: the role of customer satisfaction,trust and commitment. Maastricht School of Management, working paper No. 2014/06.

Ketprapakorn, N., \& Kantabutra, S. (2019). Culture development for sustainable SMEs: Towards a Behavioral Theory. Journal of sustainability, 11. http://doi.org/10.2290/su11092629

Kintu, I. (2017). The relationship between core values and entrepreneurial performance: A study of SMEs in the informal economy of Uganda's central region. PhD Thesis, University of Witwatersrand, Johannesburg, South Africa.

Lencioni, P. M. (2002). Mean Something: The Best of Intentions. Harvard Business Review.

Loch, C. H., Sting, F. J., Huchzermeier, A., \& Decker, C. (2012). Finding the profit in fairness. Harvard Business Review, 111-115.

Logan, T. M. (2016). Determinants of profitability of financial institutions in Latin America and the Caribbean. The Journal of Developing Areas, 4(50), 345-362. http://doi.org/10.1353/jda.2016.0168

Long, C. P. (2016). Mapping the main roads to fairness: Examining the managerial context of fairness promotion. Journal of Business Ethics, 137(4), 757-783. http://doi.org/10.1007/s10551-015-2749-3

MacCallum, C. R., \& Austin, J. T. (2000). Application of Structural Equations Modeling in psychological research. Annual Review of Psychology, 51(1), 201-226. https://doi.org/10.1146/annurev.psych.51.1.201

Madishetti, S., \& Kibona, D. (2013). Impact of inventory management on the profitability of SMEs in Tanzania. International Journal of Research in Commerce and Management, 4(2), 1-5.

Michie, S., \& Gooty, J. (2005). Values, emotions and authenticity: will the real leaders please stand up? The Leadership Quarterly, 16(3), 441-457. https://doi.org/10.1016/j.leaqua.2005.03.006

Ministry of Finance Planning and Economic Development. (2008). Enhancing the competitiveness of Micro, Small, and Medium Enterprises (MSMEs) in Uganda. Discussion paper no. 51, MFPED.

Morse, J. M., Barrett, M., Mayan, M., Olson, K., \& Spiers, J. (2002). Verification strategies for establishing reliability and validity in qualitative research. International Journal of Qualitative Methods, 1(2),1-21.

Nishimura, A. (2011). Uncertainty and management accounting: opportunity, profit opportunity and profit. Asia-Pacific Management Accounting Journal, 6(1), 81-101.

Park, K., \& Jang, S. C. (2012). Effect of diversification on firm performance: application of entropy measure. International Journal of Hospitality Management, 31, 218-228. https://doi.org/10.1016/j.ijhm.2011.03.011

Rakesh, R., Anusha, D., \& Suresh, A. (2016). A study on the impact of ethics in Indian business scenario. Journal of Economic Development, Management, IT, Finance and Marketing, 8(2), 54-65.

Reave, L. (2005). Spiritual values and practices related to leadership to leadership effectiveness. The Leadership Quarterly, 16(5), 655-687. http://doi.org/10.1016/j.leaque.2005.07.003 
Roberts-Lombard, M., Mpinganjira, M., Wood, G., \& Svensson, G. (2016). A construct of code effectiveness: empirical findings and measurement properties. African Journal of Business Ethics, 10(1), 19-35. https://doi.org/10.15249/10-1-95

Schmiedel, T., Brocke, J. V., \& Recker, J. (2013). Which cultural values matter to business process management? Results from a global Delphi study. Business Process Management Journal, 19(2), 292-317. https://doi.org/10.1108/14637151311308321

Schwartz, M. S. (2005). Universal moral values for corporate codes of ethics. Journal of Business Ethics, 59(1), 27-44. https://doi.org/10.1007/s10551-005-3403-2

Turyakira, K. P. (2018). Ethical practices of small and medium-sized enterprises in developing countries: Literature analysis. South African Journal of Economics and Management Sciences, 21(1). http://dx.doi.org/10.4102/sajems.v21i1.1756

Uganda Bureau of Statistics. (2010). Statistical abstract. Retrieved from http://www.ubos.org

Uganda Investment Authority and Ernst \& Young. (2011). Baseline survey of small and medium enterprises in Uganda. Final report.

Uganda Investment Authority. (2012). Investor survey report.

Ullman, B. J. (2006). Structural Equation Modeling: reviewing the basics and moving forward. Journal of Personality Assessment, 87(1), 35-50.

Urbach, N., \& Ahlemann, F. (2010). Structural Equation Modeling in Information System Research Using Partial Least Squares. Journal of Information Technology Theory and Application, 11(2), 5-40.

Vercio, A., \& Champion, L. (2006). Core values and costing. Chartered Institute of Management Accountants, 80(1), 26-31.

Viviers, S., Bosch, J. K., Smit, E. D. M. V., \& Buijs, A. (2008). Is responsible investing ethical? South African Journal of Business Management, 39(1), 15-25. http://dx.doi.org/10.4102/sajbm.v39i1.552

Volker, G., K., Phil, K., Yehuda, B., \& Aikaterini, M. (2018). The missing link: Fairness as the ultimate determinant of service profitability? Recherche et Applications en Marketing (English edition), 33(2), 46-74. http://doi.org/10.1177/2051570717745833

Wei, T. L., \& Yazdanifard, R. (2014). The impact of positive reinforcement on employees' performance in organisations. American Journal of Industrial and Business Management, 4, 9-12.

Wright, A. L., Zammuto, F. R., \& Liesch, P. W. (2017). Maintaining the values of a profession: Institutional work and moral emotions in the emergent department. Academy of Management Journal, 60(1), 200-237. https://doi.org/10.5465/amj.2013.0870

\section{Copyrights}

Copyright for this article is retained by the author(s), with first publication rights granted to the journal.

This is an open-access article distributed under the terms and conditions of the Creative Commons Attribution license (http://creativecommons.org/licenses/by/4.0/). 